\title{
HISTORIC INSCRIPTIONS IN PREDJAMA CAVE SYSTEM AND HIGH FLOODS IN 2010
}

\author{
ZGODOVINSKI NAPISI V PREDJAMSKEM JAMSKEM SISTEMU \\ IN VISOKE POPLAVE LETA 2010
}

\author{
Stanka ŠEBELA ${ }^{1}$
}

\begin{abstract}
UDC 551.442:003.071(497.471)

Stanka Šebela: Historic inscriptions in Predjama cave system and high floods in 2010

High floods of September 2010 partly ruined historic inscription made by charcoal »Slovenski gadje 1882« in Predjama cave system. Regarding studied historic records the September 2010 floods were the highest in Predjama at least since 1882. If we thrust the well-documented floods in 1826 they can even be higher than ones in 2010. In 2010 the water reached $489.60 \mathrm{~m}$ above the sea level at entrance parts of the cave and about 485 $\mathrm{m}$ at Vetrovna Luknja causing that the old inscription from 1882 was under water and partly destroyed. Another old inscription "Nagel 1748 «, probably done by more resistant pencil, did not suffer from the 2010 floods. Contrary, it was twice partly destroyed by carless visitors, first in 1991 and secondly in the period $1991-2005$.
\end{abstract}

Keywords: high floods, historic inscriptions, Predjama cave system, Slovenia.
Izvleček UDK 551.442:003.071(497.471)

Stanka Šebela: Zgodovinski napisi v Predjamskem jamskem sistemu in visoke poplave leta 2010

Visoke poplave so septembra 2010 delno uničile zgodovinski napis »Slovenski gadje 1882« v Predjamskem jamskem sistemu narejen $\mathrm{z}$ ogljem. Glede na preučevane zgodovinske zapise so septembrske poplave leta 2010 najvišje v Predjami, in sicer vsaj od leta 1882. Če je verjeti dobro zabeleženim poplavam 1826 bi bile te lahko celo višje kot 2010. Leta 2010 je voda v vhodnih delih dosegla $489.60 \mathrm{~m}$ nad morjem in okrog $485 \mathrm{~m}$ pri Vetrovni luknji ter povzročila, da je bil star napis iz leta 1882 pod vodo in delno uničen. Drugi podpis "Nagel 1748 «, ki je bil verjetno narejen $\mathrm{z}$ obstojnejšim pisalom, ni bil poškodovan zaradi polav leta 2010. Kljub temu pa je bil dvakrat poškodovan zaradi neskrbnih obiskovalcev, prvič v letu 1991 in drugič $\mathrm{v}$ obdobju 1991 - 2005.

Ključne besede: poplave, zgodovinski napisi, Predjamski jamski sistem, Slovenija.

\section{INTRODUCTION}

Predjama cave system (13 km of passages) represents a unique karst environment. It is the fourth longest cave in Slovenia (after Migovec cave system, Postojna cave system and Kačna Jama), which in 2011 received 6,000 visitors. Many tourists who enter the Predjama castle are becoming more and more aware of the spectacular underground cave passages as well.

The cave walls hold numerous historic inscriptions, which have been described frequently (Habe 1970; Habe 1980; Kranjc \& Malečkar 1988; Shaw 2000; Shaw 2008; Stopar 2001; Kempe et al. 2006; Čuk 2008). The earli- est dated inscription is of 1508 close to the Vetrovna Luknja (Shaw 2000, 46). In the cave we can find inscriptions of castle owners as Cobenzl (Fig. 1) and Coronini families. The mathematician Nagel from Vienna visited Predjama cave on 13 July 1748 (Kempe et al. 2006). On the limestone wall at Vetrovna Luknja there is "Slovenski gadje 1882 « inscription, representing a group of local people united in speleological interest. On the other hand the oldest archaeological layers from Konjski Hlev are from Eneolithic and some parts have Neolithic character (Korošec 1975). Konjski Hlev was used as a stable

${ }^{1}$ Karst Research Institute ZRC SAZU, Titov trg 2, 6230 Postojna, Slovenia, e-amil: sebela@zrc-sazu.si

Received/Prejeto: 3.4 .2012 


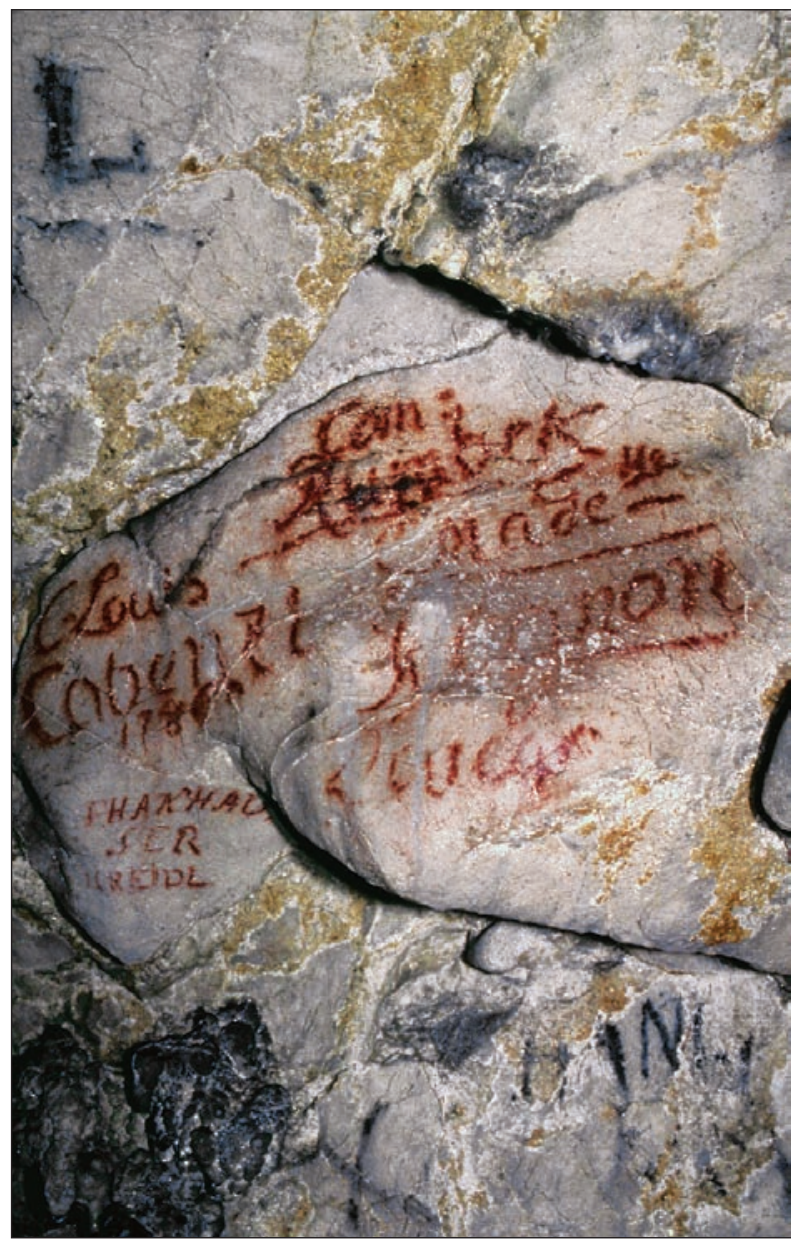

Fig. 1: Inscription of Cobenzl in Predjama cave (Photo: S. Šebela).

for horses by the owners of the castle in the Middle Ages and later.

Nagel's inscription was partly destroyed by unknown cave visitor shortly before 5 March 1991 (Drole 1991). The last number of the year 1748 was in addition partly destroyed in the period from 5 March 1991 to 19

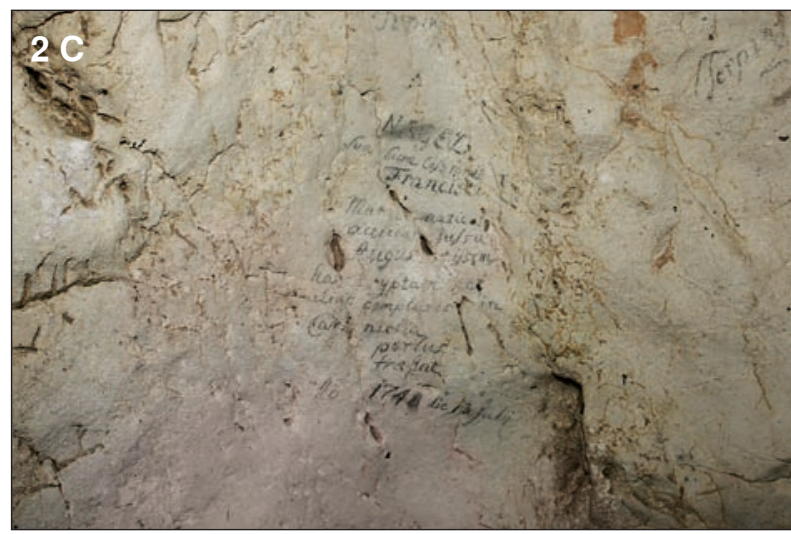

July 2005 (Fig. 2, A-C). Kempe et al. (2006) describe the $» 8$ « in $» 1748$ « somewhat blurred.

According to Kempe et al. (2006) Nagel's 1748 inscription was probably done by a metal pencil (silver, lead or tin) or a piece of sharpened mineral graphite,
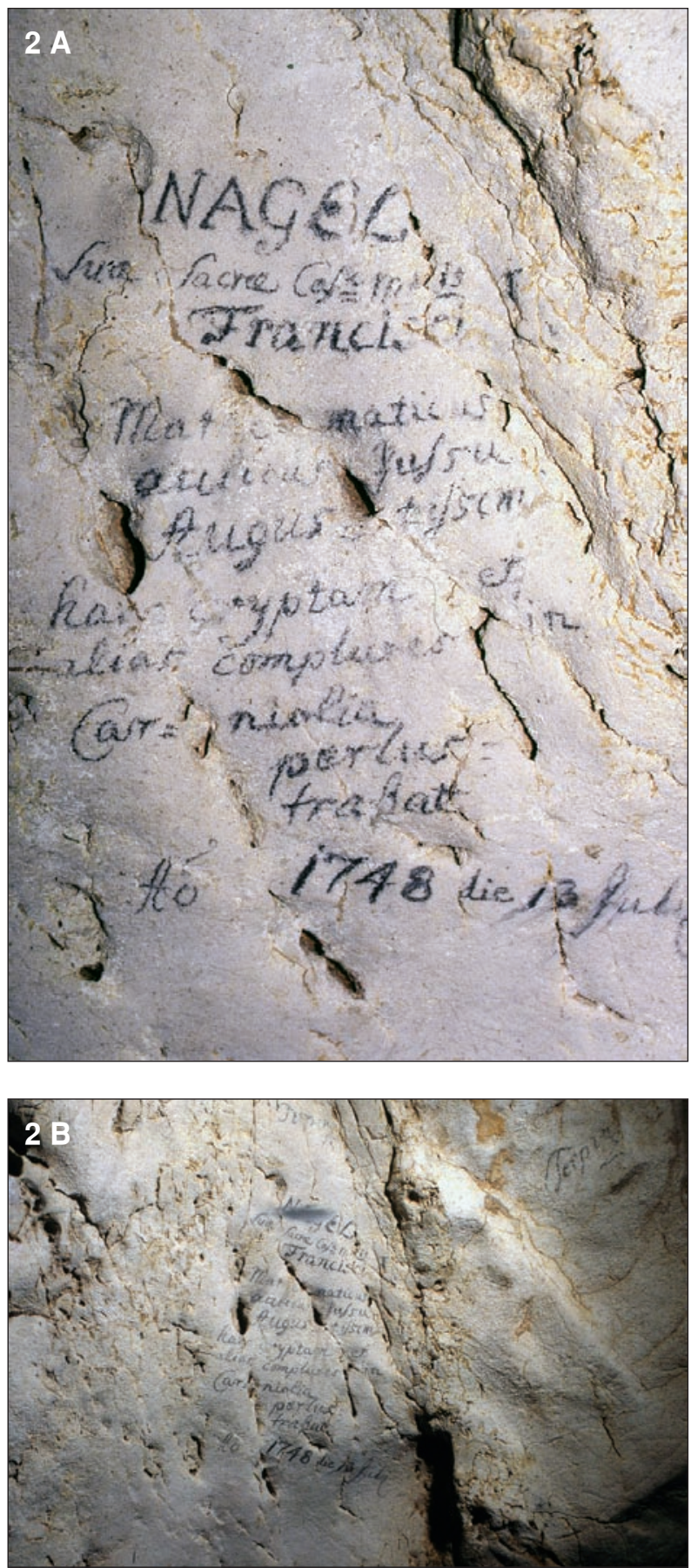

Fig. 2: "Nagel 1748« inscription. A-shortly before 5 March 1991, B-on 5 March 1991, C-on 27 September 2010 (Photo: S. Šebela). 
because clay-graphite pencil had not yet been invented. Contrary the »Slovenski gadje 1882« inscription was probably done by charcoal.

The Karst Research Institute ZRC SAZU has undertaken the functions of cave custodian in the implementation of the concession contract, meaning that we professionally monitor the state of the cave with an emphasis on the impact of the use of the cave as a natural asset (Gabrovšek et al. 2011; Culver et al. 2012). Cave custodian has important tasks regarding the implemen- tation of the concession and the state of the cave, the implementation of a rehabilitation programme to eliminate the impacts caused by the use of the natural asset. Cave custodian must also draw attention to the external factors that put the cave and cave inventory at risk. The aim of this study was to document the consequences of exceptional natural conditions (high floods in September 2010) and their impact on historic inscriptions in the Predjama cave system.

\section{STUDIED LOCATIONS AND METHODOLOGY}

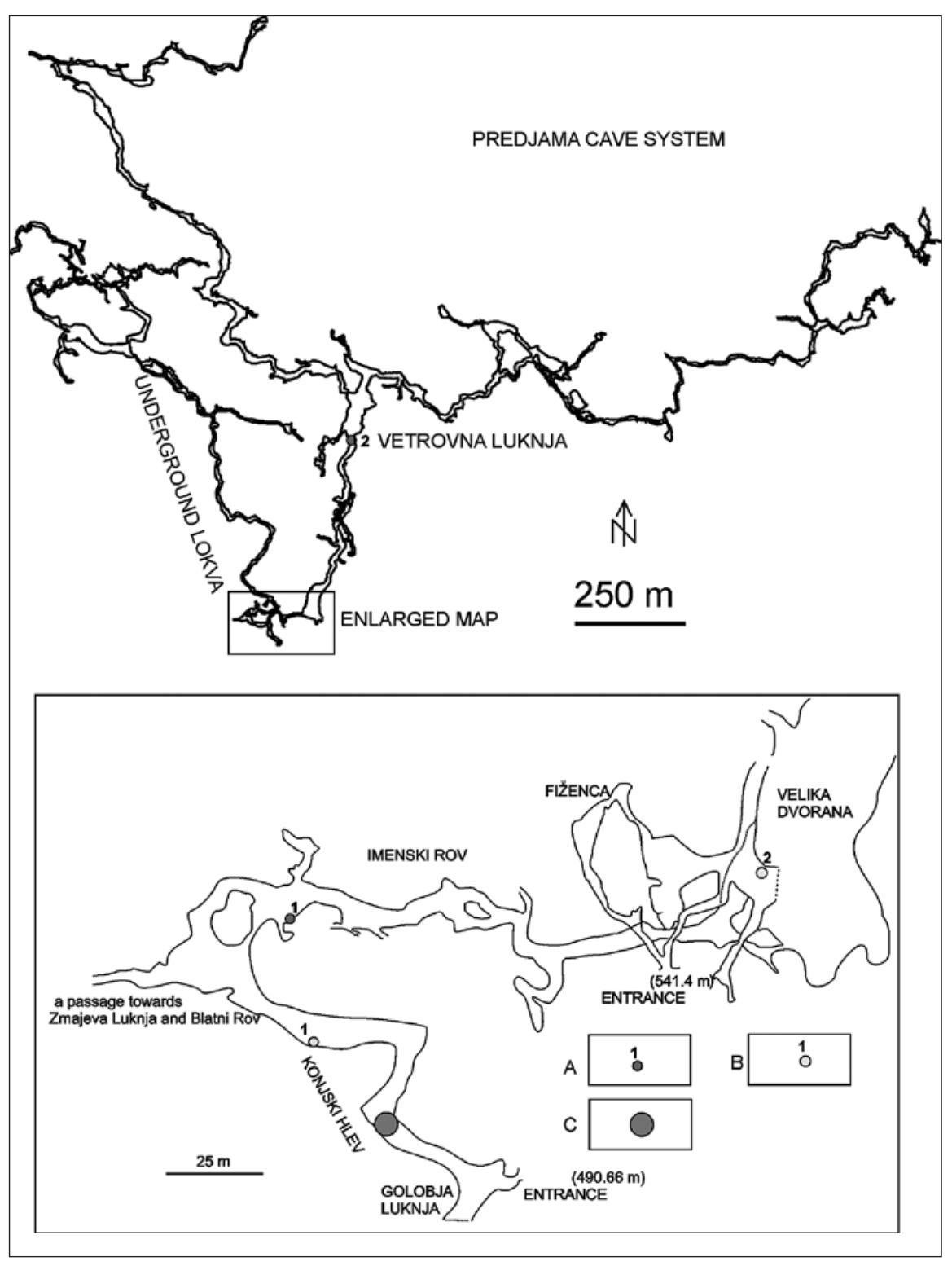

Two old inscriptions were studied in order to document the impact of high floods in September 2010. Nagel's 1748 inscription is located near Medvedja Luknja in Imenski Rov about $100 \mathrm{~m}$ far from the cave entrance and "Slovenski gadje 1882« inscription is situated on the limestone wall in front of Vetrovna Luknja about $700 \mathrm{~m}$ far from the cave entrance (Fig. 3).

The study included comparison of older photos of the inscriptions with recent situation and studies of published literature as well as field observations and documentation before and shortly after the floods in September 2010.

Fig. 3: Ground-plan of Predjama cave system. A- (1-»Nagel 1748« inscription, 2-»Slovenski gadje 1882« inscription), B- temperature data logger (1- Konjski Hlev, 2- Velika Dvorana), C-collapse due to high waters in September 2010. 


\section{HIGH FLOODS IN PREDJAMA CAVE SYSTEM}

Schmidl (1854) described catastrophic floods on Lokva River at Predjama in 1851 (Tab. 1). Wooden parts of the mill on Lokva were washed into the Blatni Rov passage. The maximum above sea level of the flood cannot be determined.

According to Habe (1966) the high floods in 1826 reached the level of $495 \mathrm{~m}$ above sea, because the anonymous witness described that water was up to the passage above the wall in Golobja Luknja. The same catastrophic event in 1826 caused the highest level of the river Reka in Škocjan Caves (Habe 1966). Maybe the level of $495 \mathrm{~m}$ is too high, because the wall at Golobja Luknja is situated at about $490-491 \mathrm{~m}$. Anyway this is the highest documented level of the floods at Predjama (Tab. 1).

Tab. 1. High floods at entrance parts of the Predjama cave system.

\begin{tabular}{l|l|l}
\hline Year & $\begin{array}{l}\text { Above sea } \\
\text { level }(\boldsymbol{m})\end{array}$ & Reference \\
\hline 1826 & 495 & Habe (1966) \\
\hline 1851 & $?$ & Schmidl (1854) \\
\hline 1965 & 488 & Habe (1966) \\
\hline 2010 & 489.30 & Šebela (2011) \\
\hline 2010 & 489.60 & $\begin{array}{l}\text { geodetic survey (performed by } \\
\text { Drole F. \& Perne M., 19 April 2011) }\end{array}$ \\
\hline
\end{tabular}

On 2 September 1965 the high waters in front of Predjama Cave reached $488 \mathrm{~m}$ above the sea level. The water was $2 \mathrm{~m}$ lower than the bridge in front of Konjski Hlev (Habe 1966).

The last record floods at Predjama were 18-19 September 2010 (Fig. 4, A-B), when the water in Konjski Hlev reached $489.30 \mathrm{~m}$ (Šebela 2011). Part of Konjski Hlev was flooded and after the retreat of the water in the night of 19

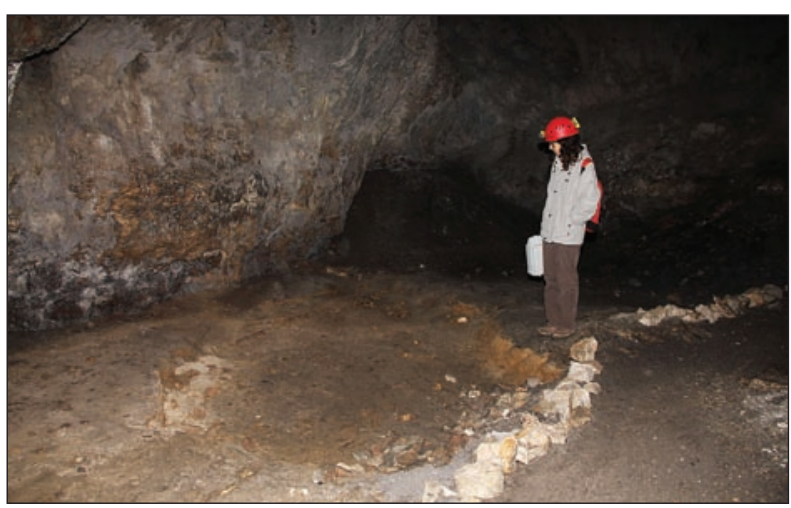

Fig. 5: Collapse in Konjski Hlev after the high floods in September 2010 (Photo: S. Šebela).

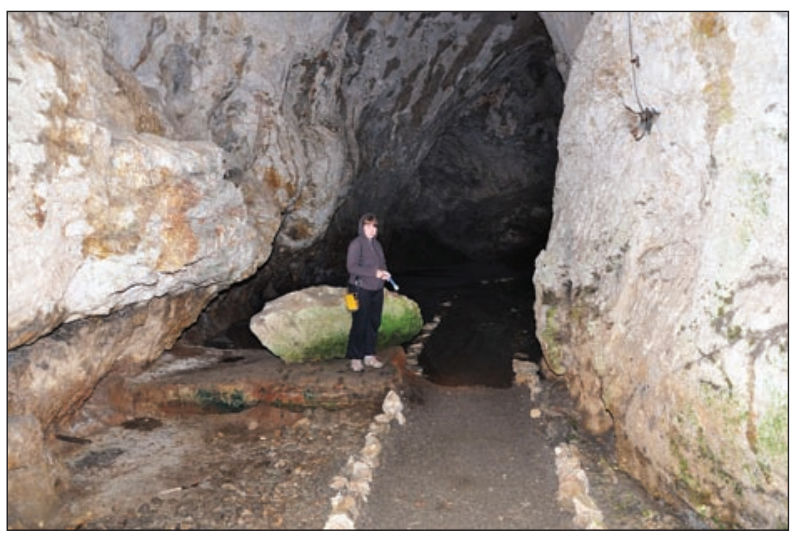

Fig. 6: High flood of September 2010 in Konjski Hlev (Photo: J. Hajna).

September 2010 the collapse $5 \times 4 \times 0.3 \mathrm{~m}$ in dimensions occurred (Fig. 5). Water must have been raised from lower passages as Zmajeva Luknja and Blatni Rov up to Konjski Hlev (Figs. 3 and 6). After detailed geodetic survey of

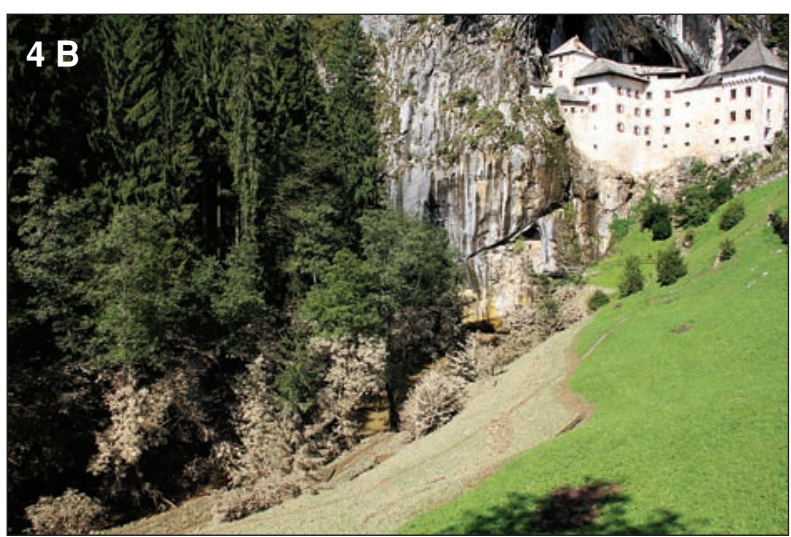

Fig. 4: High floods at Predjama. A- 19 September 2010 (Photo: J. Hajna), B- 20 September 2010, after the retreat of waters (Photo: S. Šebela). 


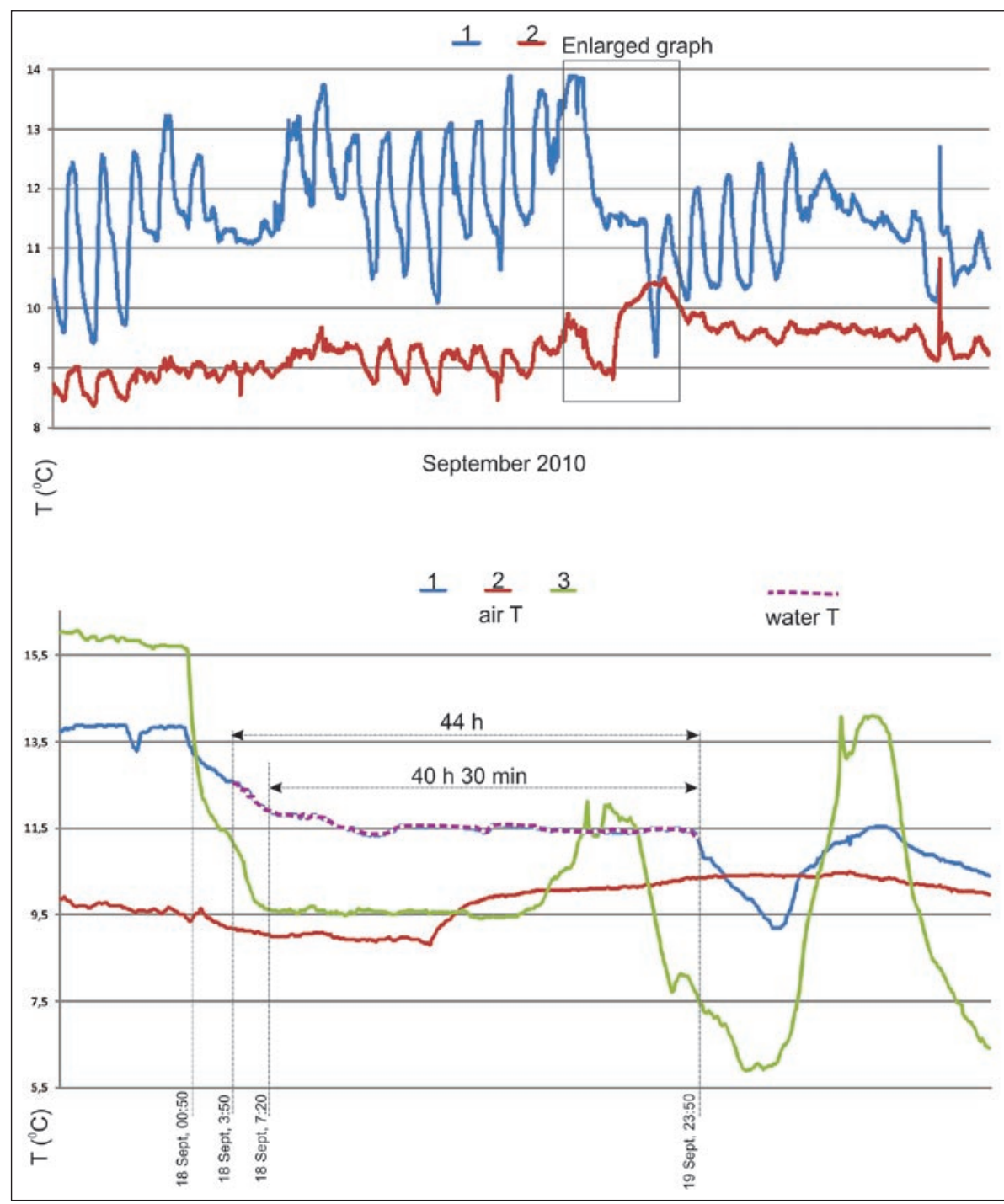

Fig. 7: Air and water temperature $\left({ }^{\circ} \mathrm{C}\right)$ during September 2010. Data were taken every 10 minutes. 1- Konjski Hlev, 2- Velika Dvorana, 3- external air temperature. the collapse on 19 April 2011 performed by Franjo Drole and Matija Perne the 2010 flood level in Konjski Hlev was determined at $489.60 \mathrm{~m}$ (Tab. 1).

Water of the last floods in 2010 covered the temperature data logger (Šebela and Turk 2011) in Konjski Hlev. But this did not harm the instrument because it is preferentially made for water measurements. On Fig. 7 air and water temperature are shown for each 10 minutes for the period of September 2010. During the floods water temperature in Konjski Hlev is almost stable; it does not show any variations. The water reached the instrument and in this way Konjski Hlev on 18 September 2010 between 3:50 and 7:20, and decreased down to lower passages on 19 September 2010 at 23:50. Regarding the data on the temperature data logger the floods in Konjski Hlev probably lasted 40 hours and 30 minutes or 44 hours in wider observation window.

\section{CONCLUSIONS}

Numerous historic inscriptions in Predjama cave system are important part of cultural heritage in the cave. Two examples were studied in the relation to extreme waters in September 2010. "Slovenski gadje 1882 « inscription at Vetrovna Luknja strongly suffered the impact of high waters (Fig. 8, C). The water reached $489.60 \mathrm{~m}$ above the sea level at entrance parts of the Predjama cave system and about $485 \mathrm{~m}$ at Vetrovna Luknja causing that the old inscription from 1882 was under water and partly destroyed. Regarding studied historic records the September 2010 floods were the highest in Predjama at least since 1882 and most probably were the second highest since the well-documented floods in 1826, which were described by Habe (1966).

The second example is the inscription of "Nagel 1748 « (Fig. 2, A), probably done by a metal pencil or a piece of mineral graphite (Kempe et al. 2006), which did not suffer much from the 2010 floods. Contrary, it was twice partly destroyed by carless visitors. First in 1991 the letter » $\mathrm{N}$ « in the name Nagel was destroyed and secondly in the period 1991-2005 the number $» 8$ « in the year number 1748 was destroyed in a same way as letter 

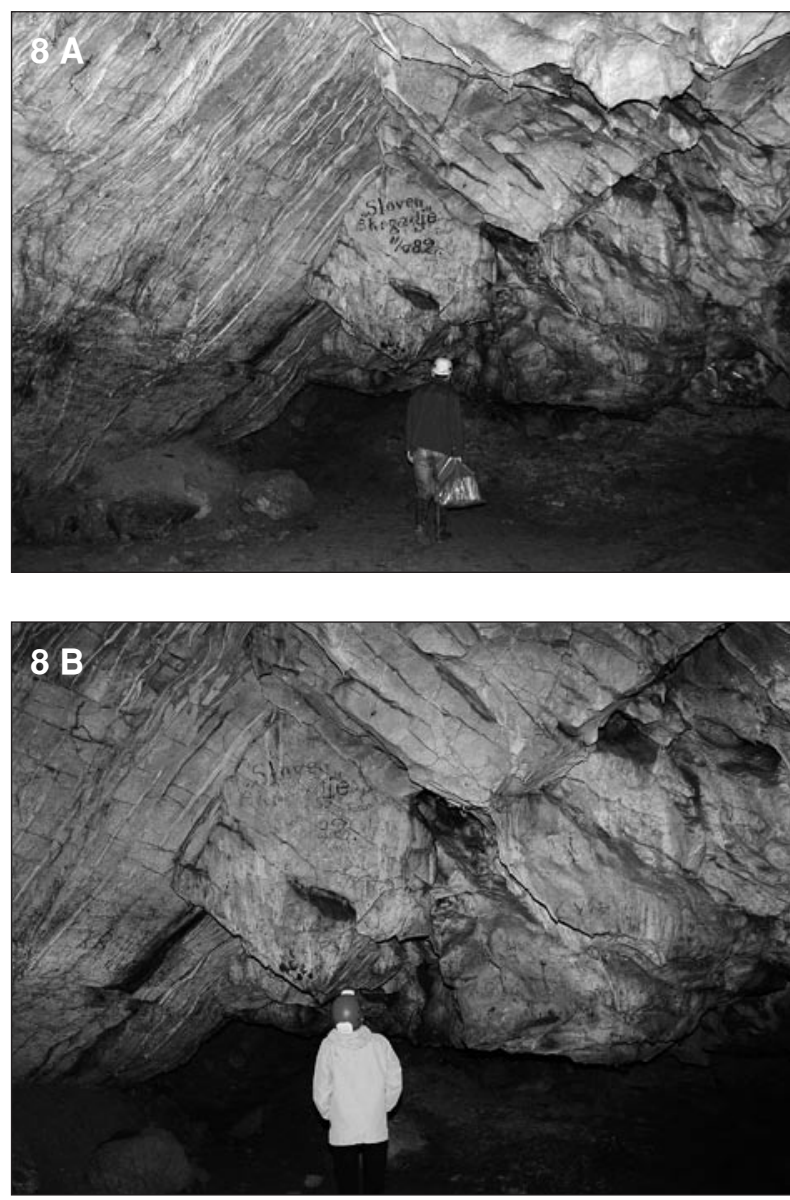

"N $\mathrm{N}$ meaning that somebody probably tried the "resistance " of letters by finger. Nagel's inscription is 134 years older than "Slovenski gadje 1882 « but because of better pencil quality resisted much better the floods.

Historic inscriptions in Predjama cave system are subject of natural and anthropogenic impacts. As cul-

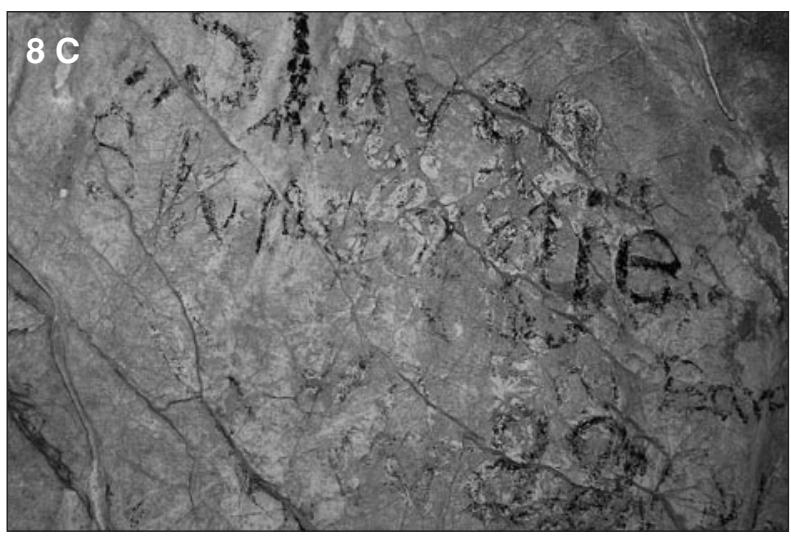

Fig. 8: Inscription of "Slovenski gadje 1882«. A-on 28 August 2009, B-on 7 March 2012, C-detail of inscription on 7 March 2012 (Photos: S. Šebela).

tural heritage of the national importance they must be strongly protected, especially against bad intentional and not-professional interventions. On the other side the last high floods of September 2010 showed that old inscriptions are also subject of exceptional natural situations. Regarding this, possible professional restoration treatment of damaged inscription can be considered. It is also very important that scientists and other professional workers (cave guides, speleologists, representatives of Regional Units of the Institute of the Republic of Slovenia for Nature Conservation, cave custodian etc.) entering the cave regularly take pictures and notices on their trips to the underground, making important archives for the state of the cave during different periods.

\section{ACKNOWLEDGEMENTS}

The author is thankful to Ksenija Dvorščak, Sergeja Kariž and Janez Margon (Postojnska jama d.d.) for informations about high floods in 2010. Jure Hajna (ZRC SAZU) is author of Figures 4A and 6. Franjo Drole (ZRC SAZU) and Matija Perne on 19 April 2011 made the geodetic survey of the collapse in Konjski Hlev. The study was part of the projects "Expert control and recommendations for management of cave systems" and "Climatic and biological monitoring of cave systems" financed by Postojnska
Jama d.d. It is also part of "Karst Research Programme" (P6-0119), "Measurements and Analysis of Selected Climatic Parameters in Karst Caves: Example of the Postojna Cave System" (L6-2156) co-financed by the Slovenian Research Agency, Postojnska Jama d.d. and Meis d.o.o., IGCP-UNESCO Project 598 "Environmental change and sustainability in karst systems" and EU FP7 IRSES project "BlackSeaHazNet". 


\section{REFERENCES}

Culver, D. C., Debevec, B., Knez, M., Kovačič, G., Kranjc, A., Mulec, J., Pipan, T., Prelovšek, M., Ravbar, N., Semeja, A., Slabe, T., Šebela, S. \& N. Zupan Hajna, 2012: Karstology and development challenges on karst II, construction, tourism, ecology, protection.Založba ZRC, pp. 199, Postojna-Ljubljana.

Čuk, A., 2008: Postojna Cave.- Turizem Kras, destinacijski management, ČukGraf, pp. 112, Postojna.

Drole, F., 1991: Objestnost ne pozna meja.- Naše jame, 33, 154-155.

Gabrovšek, F., Knez, M., Kogovšek, J., Mihevc, A., Mulec, J., Perne, M., Petrič, M., Pipan, T., Prelovšek, M., Slabe, T., Šebela, S. \& N. Ravbar, 2011: Development challenges in karst regions: sustainable land use planning in karst of Slovenia.- Carbonates Evaporites, 26, 365-380.

Habe, F., 1966: Katastrofalne poplave pred našimi turističnimi jamami.- Naše jame, 8, 45-54.

Habe, F., 1970: Predjamski podzemeljski svet.- Acta Carsologica, 5, 7-94.

Habe, F., 1980: Predjama - grad in jama.- Postojnska jama, turistično hotelska organizacija, GP »Soča», pp. 43, Postojna.
Kempe, S., Hubrich, H.-P. \& K. Suckstorff, 2006: The history of Postojnska jama: The 1748 Joseph Anton Nagel inscriptions in Jama near Predjama and Postojnska jama.- Acta Carsologica, 35, 2, 155-162.

Korošec, P., 1975: Eneolotik Slovenije.- Arheološki vestnik, 24 (1973), 167-216.

Kranjc, A. \& F. Malečkar, 1988: Postojnska jama 170 let odkrivanja, raziskovanja in turističnega razvoja.Postojnska jama, turistično hotelska organizacija, Tiskarna Tone Tomšič, pp. 32, Ljubljana.

Schmidl, A., 1854: Die Grotten und Höhlen von Adelsberg, Lueg, Planina und Laas.- Akademie der Wissenschaften, V-VIII, pp. 3-314, Wien.

Shaw, T., 2000: Foreign travellers in the Slovene karst 1537-1900.- Založba ZRC, pp. 244, Ljubljana.

Shaw, T., 2008: Foreign travellers in the Slovene karst 1486-1900.- Založba ZRC, pp. 338, Ljubljana.

Stopar, I., 2001: Predjamski grad.- Postojnska jama turizem d.d., Tiskarna Ljubljana, pp. 128, Ljubljana.

Šebela, S., 2011: Izjemni naravni pojavi v Postojnskem in Predjamskem jamskem sistemu.- Annales Ser.hist. nat, 21, 87-94.

Šebela, S. \& J. Turk, 2011: Air temperature characteristics of the Postojna and Predjama cave systems.- Acta Geographica Slovenica, 51, 1, 43-64. 